\title{
1. Problematic premises: positivism, modernism and masculinism in IPE
}

\author{
V. Spike Peterson
}

Questions of conceptualization are questions of power. (Mies 1998, p. 36)

\section{PROBLEMATIC PREMISES}

How is feminist International Political Economy (IPE) affected by the conceptualizations and power relations pervading conventional approaches to IPE? This is the question I explore in this chapter, and do so with two entwined objectives: to survey how 'problematic premises' - of positivism, modernism and masculinism - underpin and constrain dominant modes of theorizing IPE; and to consider how these premises shape interpretations of, responses to, debates within, and the current theory/practice of feminist IPE.

To further contextualize this exploration, I indicate key starting points framing the chapter. First, I assume a critical orientation toward (neoliberal) capitalism understood as inextricably socio-cultural, economic and political processes, operating worldwide across 'levels of analysis' and promoting a polarization of rich-poor (within and between states/nations) and attendant, systemic harms. Second, my critical orientation toward capitalism is part of a more encompassing critique being developed primarily by feminists engaged in critical analyses of intersectionality. ${ }^{1}$ Zillah Eisenstein (1998) contends that key structural hierarchies - of class, national 'difference,' ethnicity/race and gender/sexuality - constitute 'capitalist racist patriarchy' on a global scale. The theory/practice of capitalist racist patriarchy (henceforth, CRP) is the target of this larger critique, which follows from additional starting points: that feminist theory/ practice seeks not only to 'empower women' but to advance critical analysis and transformation of multiple, intersecting structural hierarchies, and that this entails not only a critique of 'patriarchy' but also a critical interrogation of its interaction with arguably co-constitution of - capitalism and racism. ${ }^{2}$ This larger critique requires attention to the problematic premises of positivism, modernism and masculinism (henceforth, PMM) as well as their interactive effects.

The chapter first briefly clarifies some key terms and organizational framing, then surveys how PMM commitments variously appear in orthodox International Relations (IR) and Economics and in both orthodox and heterodox IPE. This survey reveals these premises operating as both impediments to transformative critiques of CRP and as resistances to feminist IPE. I argue that while these conceptualizations operate differently in different discourses, the interaction of them typically obstructs historical, 


\section{Handbook on the international political economy of gender}

holistic and critical theory/practice. The next section focuses on feminist IPE, considering its relation to PMM premises and surveying the expanse of feminist interventions, internal debates and continuing issues.

\section{POSITIVISM, MODERNISM AND MASCULINISM}

My representations of PMM in this chapter are based on the critical work of poststructuralist, postcolonial and feminist scholars. ${ }^{3}$ This critical work exposes how underlying assumptions - conceptualizations - are simultaneously political (reproducing relations of power) and material (producing material effects).$^{4}$ Due to long histories of stabilization/normalization, PMM premises often operate below a conscious level arguably, as 'common sense' - and thus elude scrutiny and critical interrogation (Peterson 2010b). The more familiar route of criticizing these orientations in isolation from each other has been productive, but fails to analyse the varying and relatively pervasive ways in which PMM premises interact in IPE theory/practice. While I argue that these premises for the most part impede critical intersectional analysis, they interact in complex and not always predictable fashion: often as mutually reinforcing, yet also with tensions and even contradictions. Hence, I attempt to read them 'in relation,' especially the convergences they exhibit and which undergird the Western episteme, its inequalities and its re/production of CRP. A more fully formed critique of the latter is what I deem crucial for more adequate feminist IPE.

Positivism is arguably the most familiar and reflects the hegemony of rationalist, objectivist methods of inquiry favored in the social sciences. Its conceptualizations tend toward ahistorical, reductionist analyses and invoke dichotomized terms as oppositional and hierarchical. The stability of 'bounded' (discrete, homogeneous) concepts facilitates calculation and prediction, which are presumed necessary for objectivity and parsimony but effectively exclude subjectivity, emotions, ambiguity and complexity. Critiques of positivism are well rehearsed and underpin, especially, poststructuralist analyses. $^{5}$

Modernism references the privileging of Western-centric knowledge, practices and policy-making as constitutively 'superior.' Merged with positivism, its conceptualizations feature ahistorical narratives, essentialized categories, hierarchical dichotomies (modern-traditional, North-South), 'scientific' reasoning, and instrumental, top-down and 'problem-solving' orientations. Certainty and control are privileged over contestation and critical reflection. Its priorities favor individualism and elite knowledge producers, and its presumption of Western superiority (liberal democracies, capitalist economies) justifies indifference to or devalorization of the experiences, knowledges and voices of 'Others,' which is inseparable from racist ideologies borne of Europe's colonizing and capital accumulation practices. Critiques of modernism are especially well developed in postcolonial analyses, which are often informed by Marxist and poststructural insights.

Masculinism owes much to (modernist) conceptualizations of generic 'man' (atomistic, self-interested, acquisitive, competitive) that are conventional 'foundations' of political and economic theory (liberal, capitalist). In this chapter masculinism references the governing gender code privileging that which is associated with masculinity 
(reason, agency, autonomy, control) at the expense of that which is feminized (objects, skills, identities, ways of thinking and doing) (Peterson 2005). It thus presumes and (re)produces asymmetrical social arrangements, categorical Othering, and the cultural and material devalorization of feminized qualities and subjectivities (not only females). Critiques of masculinism, of course, underpin feminist analyses, which vary with reference to positivist and modernist commitments.

IPE is a relatively recent academic field of inquiry, taking shape in the 1970s as global dynamics were undergoing more than the usual turbulence. It is no surprise that early analysts relied heavily on the disciplines of IR and Economics in constituting IPE as a relatively independent area of research. Given the significance of these disciplinary 'legacies' for today's IPE (Murphy and Tooze 1991a; Hodgson 1994), the chapter sequentially examines positivism, modernism and masculinism as they appear in orthodox/mainstream IR, Economics and IPE, then in heterodox IPE and finally, feminist IPE. While I recognize that there are important differences in the degree to which heterodoxies and orthodoxies rely on PMM premises, my discussion simplifies in order to reveal problematic patterns across the spectrum of IR, Economics and IPE inquiry.

\section{POSITIVISM}

Positivism - in its many guises - remains central to social scientific inquiry: acclaimed in orthodox accounts as indispensable for objective and 'realistic' analysis, and retained (while often disdained) in many heterodox accounts. In mainstream IR, positivism fuels separations of the international from the national 'level of analysis,' which reproduces the presumption of territorially bounded sovereign nation-states and corollary dichotomies of external versus internal and anarchy (disorder, chaos, rivalry without) versus government (order, sovereignty, nationalist 'community' within). Power is typically viewed in terms of material, especially military, resources, hence as direct, top-down, 'power over' rather than indirect, structural, discursive or disciplinary. Realist accounts prioritize (hard) power politics over (soft) economic arrangements, and liberals prize a public-private 'divide' registered in ambivalence regarding appropriate interventions by governments in market operations. And not least, surfacing persistently in various ways, is a separation of politics/power from economics/markets, as well as a conventional distinction between public/government and private/business spheres of activity.

Orthodox Economics is explicit in dividing politics from economics and occluding political power more generally. The public-private division is read as states versus markets (and in the process excludes the 'private' family/household from 'economic' analysis). Additional binaries separate macro from micro, formal (recorded, regulated) from informal (unofficial, irregular) economic activities, and productive (paid, growth enhancing) from reproductive (necessary but unpaid, not productive, merely subsistence-based) activities. Hegemonic neoclassical models simply exclude issues of preference formation (values), structural inequalities, and imperialist, racist relations of power. A positivist growth model is relentlessly promoted while its environmental effects are deemed external to economic rationality. 
Dominant approaches in both fields eschew that which defies rigid categorization, calculation, modeling or quantification, that is, affect, allegiance, subjectivity and the vast array of cultural phenomena emphasized by poststructuralists. While geopolitical discourse divides 'the West' (liberal democracies with effective governments) from 'the rest' (socialist, failed or rogue states, inept or tyrannical governments), socio-economic discourse divides the North (developed, advanced industrialized 'free market' and formalized economies in capitalist mode) from the South (developing or weakly industrialized economies, poorly formalized markets).

To the considerable extent that IPE draws its theory from IR and its methods from Economics, it fails to distance itself from well-rehearsed critiques of each. While the naming of the field suggests a merging of politics and economics, many note a continuing dichotomy in actual studies (e.g., Nitzan and Bichler 2009). At the same time, orthodox IPE - especially in the United States - 'is avowedly positivist and empiricist, ... claiming legitimacy from a notion of science' (Murphy and Tooze 1991b, p. 17). As revealed in popular textbooks, IPE assumes state-market interactions as the core issue and how to explain 'what drives the world economy' as its core question.

The expanding field of heterodox IPE presents a more complicated picture, given its critical commitments and varying engagement with Marxist, world systems and anti-imperialist analyses. ${ }^{6}$ Yet even heterodox IPE features conventional binaries (security-conflict, international-national, formal-informal, productive-reproductive), levels of analysis that exclude the family/household, methodologies that exclude affect and subjectivities, and often advocates instrumental (rather than 'critical') approaches.

In sum, positivist commitments prioritize stable (essentialized), discretely bounded categories that afford calculability, accommodate quantitative methods and promise predictability. One effect is top-down, instrumental applications that perpetuate hierarchical relations. Another effect is the marginalization of history, culture, affect and indirect operations of power. Not least: positivism can only 'add' gender as an empirical category and not engage analytical gender and its transformative implications.

\section{MODERNISM}

Referencing 'modernism' draws historical attention to Eurocentric, colonial and imperialist interests and practices and their continuing effects in the twenty-first century. 'The West' claims authorship - and 'ownership' - of Enlightenment ideals (freedom, equality, rationality, progress) and processes for realizing them (liberal democracy, objectivist science, sovereign states, capitalist industrialization). Less often does 'the West' acknowledge the manifestations of colonialism, racism, heterosexism and increasing environmental degradation that are inextricable from the 'modernization' processes it trumpets. Critical theorists continue to ponder whether or how the liberal ideal of both freedom and equality might be realized while pursuing capitalist development that is at best 'uneven' and at worst constitutively exclusionary and hierarchical. The quandaries have thus been variously articulated, yet are rarely addressed in mainstream accounts. At the same time, awareness of these problematics, 
and their ethical implications, prompts some reticence to explicitly claim 'modernist' (Western-centric, imperialist, racist) commitments.

In IR, modernism is especially evident in a preoccupation with the most powerful states, (what are in effect) neo-colonial and imperialist interests and practices of those states (through foreign policy priorities, military alliances, dominance in international organizations), and maintaining a geopolitical status quo that favors 'the West' (Marchand and Runyan 2011). Postcolonial scholarship, with its critiques of Western dominance and arrogance, makes an occasional appearance in IR and IPE literatures, but the challenges and questions it raises are rarely engaged. ${ }^{7}$ Particularly remiss is the lack of critical race studies outside of postcolonial writings and some interventions by critical scholars (Grovogui 2001; Rupert and Solomon 2006; ISP Forum 2009). Rather, when problems of 'difference' emerge they are 'addressed' primarily through 'rescue narratives' whereby the most powerful states exercise foreign policies in the guise of 'saving the world' for the freedoms promised by democracy. Recall how in post-9/11 military interventions the United States manipulated a crusading logic of 'liberating women' in Afghanistan and Iraq (rescuing them from their 'own' men/race/culture), which obscured the racialized, imperialist agenda of these military actions.

Modernism in Economics is evidenced by its positivist (ahistorical, decontextualized) commitments, instrumental applications and presumption of Western 'superiority' in theory/practice (Zein-Elabdin and Charusheela 2004). Mainstream theorizing remains focused on territorially based national economies, especially those of the global North; non-Western economies are relegated to the subsidiary field of 'development economics,' where the objective is to 'assist' the 'catching-up' process through modernization projects. The presumed superiority of Western theory/practice appears here in rescue narratives whereby international organizations (dominated by the global North) impose economic policies - credit and debt 'management,' micro-credit financing, 'development through remittances' - in the guise of 'saving' national economies for the abundance promised by capitalism. Like IR, Economics presumes a model of human subjectivity (rational/economic 'man' as an autonomous, self-interested, resource maximizer) and methodological ideals drawn from (modern) European philosophy. Economics resiliently foregrounds methodological individualism and rational choice and privileges 'scientific' formalist, statistical and quantitative analyses predicated on ontologically discrete - countable and calculable - categories, hence, marginalizing issues of affect, embodiment, subjectivity and culture. ${ }^{8}$

Orthodox IPE - especially in the United States - retains much of this problematic theory/practice, as revealed in IPE's failure to 'globalize,' its preoccupation with exclusively 'trans-Atlantic' debates, and the various ways in which it exhibits a common sense that 'the West knows what is best for the Rest' (Beier 2005; Gruffydd Jones 2006). Postcolonial critiques rarely appear in orthodox IPE. In one sense, orthodox IPE's resistance to poststructuralism fuels indifference to, ignorance of and/or resistance to postcolonial work that often features a poststructuralist orientation (as argued in Peterson 2005; De Goede 2006). In a second sense, resistance is due to subordinating the interests and knowledge of 'Others' when the high stakes of geopolitics and IPE are at issue (Rupert and Solomon 2006). In these fields and in 


\section{8}

Handbook on the international political economy of gender

multiple senses, the ahistorical, instrumental (top-down, problem-solving) and dichotomizing tendencies of positivism merge with and perpetuate modernist commitments and exclusionary practices.

In contrast, most heterodox (critical, Marxist, feminist) IPE scholars identify with constructivist - and some with poststructuralist - orientations that are avowedly more historical, reflective and suspicious of conventional 'givens.' These scholars more frequently challenge neoliberal policies, Eurocentric theorizing and ahistorical analyses. They examine, for example, the problematic continuity of informal work in the global South, its expansion in the global North, and the implications of illicit (grey/black market, fraudulent, criminal) informal activities as security concerns (Friman 2009; Peterson 2010a). These studies expand the terrain of IPE inquiry and questions asked, but primarily to determine how informal arrangements do, do not or might facilitate productivity, development or 'security' understood in (modernist) capitalist and Western-centric terms (e.g., ILO 2008). In this sense, scholars simply 'add' informal activities to market and IR frameworks, rather than interrogate their interdependence, and we see again the resilience of positivist and modernist assumptions that obstructs a fuller engagement with poststructuralist, postcolonial or feminist interventions.

\section{MASCULINISM}

Compared to positivism and modernism, masculinism as a way of thinking, acting and identifying is rarely examined or even taken seriously as constitutive of the theory/ practice of IR, Economics and IPE. Interacting with positivism, masculinism appears in the androcentric (male-as-norm) model of human nature (atomistic, self-interested, competitive) and the discrete, essentialized categories of male and female (in that order). Similarly, sex difference, heteronormativity and heteropatriarchal family formations are presumed 'givens,' ignoring their historical production in political and economic processes (Peterson 2014a). Essentialized categories preclude intersectional investigations of subjectivities and their complex effects. At best, 'women' (as an empirical category) may be 'added to' existing analytical frameworks, but gender (as a governing code of asymmetrical valorization) remains unacknowledged and its theoretical implications unexamined. Instead, when gender does appear, it is understood as a synonym for 'women' and treated as a 'special interest' rather than a systemic issue. This disregards feminist insistence that gender research tells us as much - if not more about men and masculinity as it is does about women and femininity (e.g., Tickner 2005; Parpart and Zalewski 2008).

Interacting with modernism, masculinism appears in a presumption of human nature that is not only androcentric but augmented by Western-centric claims to superiority: in power, authority, political acumen, scientific rationality and top-down 'problem solving.' Similarly, masculinism assumes entitlements: to speak and act on behalf of Others (erasing their autonomy, agency, authority and knowledge claims), and to determine what counts (is valued) and who counts (is recognized/respected) in geopolitics and IPE. 
Feminist research has extensively documented the masculinism of orthodox IR, where males dominate in a discipline that focuses on male-centric activities (militarism, foreign policy, 'big business') and is preoccupied with 'hyper-masculinity' (celebrating masculinized characteristics of power-over, aggression, competition). Even the emerging literature on 'human security' either fails to encompass 'women' or represents them primarily as 'victims' (hence, needing protection or rescue). Especially glaring is IR's inattention to gender coding and how masculinist beliefs and identities shape (and are shaped by) animosities, inequalities, (in)securities, conflicts, competition and war-making (Hooper 2001; Peterson 2007; Hutchings 2008).

Feminists have similarly critiqued Economics where rational, acquisitive 'economic man' is the decision-maker and breadwinner and 'women's work' is simply irrelevant (Barker and Feiner 2004). The masculinism of Economics is legible as well in its prevailing categories and the (gendered) hierarchical valorizations they privilege: markets-households, production-reproduction, paid-unpaid work, formal-informal, growth-sustainability. The expansion of flexibilized, informal and precarious work features prominently in today's economic arrangements, yet its pervasively gendered aspects are invisible in orthodox analyses (Chant and Pedwell 2008; Peterson 2010a). If the hyper-masculinity of power politics and militarism resists feminist interventions in IR, the entrenched hegemony of neoclassical theory resists critique in Economics.

Orthodox IPE is no better, as it resists acknowledging - much less integrating gender, in spite of earlier interventions by Marxist/Socialist feminists and the recent expansion of gender/feminist IPE studies. Hence, mainstream accounts inadequately analyse how accumulation processes (and citizenship claims) are shaped by heteropatriarchal arrangements, how the social order depends on reproductive and caring labor, and how sexual/affective relations are altering 'family'/household arrangements worldwide (Peterson 2014b). Ignoring these aspects of IPE impoverishes, for example, our understanding of labor markets, shifting values, migration patterns and politics, and global householding practices (see Chapters 19 and 29).

We might expect that constructivist/poststructuralist IPE scholars - who recognize power operating through discursive, cultural and disciplinary processes - would recognize the power of gender as a governing code, especially as it shapes economic valorizations (what we desire, who does what work, with what reward or respect). Heterodox IPE does increasingly acknowledge gender, but primarily by 'adding' it as an empirical category, or including a section on gender in introductory texts or a feminist chapter in edited volumes. In sum, aside from self-identified feminist scholarship, one rarely finds any explicit critique of masculinism - or gender more generally - in IPE research and publications. ${ }^{9}$ This failure to engage gender as an analytical/theoretical category keeps masculinism as a governing code of privilege and hierarchical valorization invisible.

\section{PMM IN FEMINIST IPE ${ }^{10}$}

My account suggests how PMM premises not only constrain and impoverish dominant accounts of IPE, but also how they fuel resistance to critical perspectives, including those of feminist IPE. More specifically, their conceptualizations obstruct perspectives 
necessary for 'seeing' and critically analysing the inequalities of today's CRP. How then does feminist IPE adopt, complicate and/or resist these 'problematic premises'?

With respect to epistemological/methodological matters, feminists are generally pluralists and rely on a wide variety of methods (Ackerly et al. 2006). Given feminist normative commitments, studies often use gender as an empirical category to reveal patterns in how being male or female affects, and is affected by, prevailing conditions of IPE. 'Adding' females, their experiences and knowledge to existing analytical frameworks reveals omissions, alters questions, revises categories, expands inquiries and enlarges our knowledge base, especially regarding the interdependence of masculine-feminine identifications, subjectivities, ideologies and activities.

By deploying gender empirically and investigating links among households, markets and states, feminist IPE produces more accurate knowledge of intra-household labor and resource allocation, expands quantitative measures of 'economic success' to include measures of human well-being, and demonstrates the significance of 'women's work' at every 'level' of global economics. By attending to sexual politics, feminists analyse how accumulation processes (and citizenship claims) are shaped by heteropatriarchal arrangements, how the social order depends on reproductive and caring labor, and how sexual/affective relations are altering 'family'/household arrangements worldwide. ${ }^{11}$ Incorporating gender (more accurately: sex difference) as a variable across various studies generates new knowledge but also raises troubling questions. Simply 'adding women' left glaring problems intact: for example, the 'cheapening' of women's labor in the formal economy (Enloe 2014), and relying on women to 'take up the slack' - sometimes working a triple shift in familial, informal and formal activities - without altering men's roles or gender relations (Rai et al. 2014).

Feminists adopting more constructivist/poststructuralist orientations reject simplifying binaries, recognize the 'force' of affective commitments, and emphasize power relations as discursive and cultural as well as material (Griffin 2011, 2013). These researchers critique essentialist identities in favor of exploring intersectionality and its complexities. Hence, they grapple with issues of 'difference' - racism, classism, imperialism - typically neglected in mainstream accounts (Ling 2002; Agathangelou and Ling 2009). A poststructuralist lens renders the governing code of gender visible, and reveals how that which is feminized (skills, jobs, ways of thinking, doing, being) is devalorized both conceptually (status) and materially (compensation). This systemic insight illuminates valorizing processes that pervade economic conditions, as well as everyday lives (Peterson 2003; Elias 2010, 2011).

With respect to modernism, feminists adding gender as a variable to 'modernization' studies challenged claims that economic development benefitted everyone. They demonstrated how mainstream exclusion of women's roles and household dynamics generated faulty analyses and jeopardized development objectives (Elson 1991; Rai 2002, 2008). As 'women' became more visible in development studies, feminists pondered and continue to debate whether and how Western-defined forms of 'inclusion' - gender mainstreaming, micro-lending projects, home-based handicraft work for global markets, 'the business case' for gender equality - are actually 'good' for women, or for which women. ${ }^{12}$ Related to these concerns, feminists also contribute to and expand Marxian and world system critiques of Western-centric, capitalist 'development' policies, including analyses of 'primitive accumulation.' ${ }^{13}$ In the context of 
neoliberal restructuring, feminists diagnose how modernist premises operating in mainstream and critical approaches compromise their analyses of, for example, expanding licit and illicit informal activities, the insecurities these entail, and the crisis of social reproduction that unfolds as more is expected of women even as resources available to women for ensuring social reproduction decline (Bakker and Gill 2003; Bakker and Silvey 2008).

Feminists investigate linkages between domestic, reproductive labor and a wide range of informal revenue generating activities, and in the process expose the structural (inter)dependence of productive, formal economic activities on reproductive, informal ones (Chant and Pedwell 2008; Peterson 2012). They track the relationship between affluent consumerism in the global North and abject production processes in the global South, and pay particular attention to gendered migration patterns, 'development via remittances' and the racialized aspects of global 'care' chains (Parreñas 2001; Kofman 2004; Beneria 2008; Kunz in this volume). These processes involve dramatic increases in 'global householding' that warrant much closer critical attention in IPE. ${ }^{14}$ Feminists also examine the gendered aspects of financial markets (Peterson 2003; Agathangelou 2013; Griffin 2013) and the effects of severe debt and financial crises in the global South during the twentieth century, and worldwide in the wake of the recent, arguably ongoing, crisis triggered by predatory financial arrangements in the rich North (Gender \& Development 2010; Griffin 2013; Elson 2014). And for decades, feminists have been attempting to improve conditions for 'women' through transnational and global conferences, networking, collaborative research, and activist pressure on national and intergovernmental policy-making (Hawkesworth 2006; Runyan and Peterson 2014).

From more poststructuralist and especially postcolonial perspectives, feminists have problematized claims of Western superiority - including Western feminisms - and exposed the racism of neo-colonial practices (Ling 2002). They have queried the meaning and even the desirability of 'development,' interrogated Eurocentric definitions of work and how to 'count it,' and probed the implications of Western, capitalist growth models for (re)producing structural inequalities, intense insecurities, violent confrontations and environmental degradations (Runyan and Peterson 2014). They draw attention to the dictates of neoliberal governmentality and its increasing expectations of self-management and self-entrepreneurship, even as precarity characterizes conditions of the global majority. Since 9/11 and the US 'War on Terror,' feminists have examined how gender as well as race, class and national location shape, and are shaped by, the 'twins' of neoliberalism and neo-imperialism (Peterson 2007; Marchand and Runyan 2011). And feminists are at the foreground of integrating cultural, political and economic operations of power, and analysing their implications for in/security from the intimate to the international, including the embodied politics of incarceration and 'intimate war.' 15

A summary view suggests that positivist and modernist premises variously appear in feminist IPE, with variously productive and problematic implications. On the one hand, our complicity in presuming Western superiority, its Othering, silencing, exclusionary and exceptionally predatory practices, and its militarized neo-imperialism is too easily evaded and hence too rarely interrogated. On the other hand, the increasing presence of poststructuralist and postcolonial perspectives in feminist IPE affords alternative, more critical and often quite challenging analyses. They more incessantly ask the more 
difficult questions, but as critics note, their complex interpretations often frustrate our longing for 'answers' in the face of urgent questions.

With respect to masculinism, feminists certainly lead in critical inquiry and quality research. We might assume that, by definition, feminist scholarship involves some critique of sex/gender inequality, but here I draw attention to variations among 'gender researchers.' Those who work primarily with data sets and quantitative methods necessarily rely on gender as empirical categories - male and/or female - which can be manipulated as variables in complex research designs. As noted above, this generates a wealth of data for analysing how being male or female in IPE affects, and is affected by, an endless array of variables across many measures, activities, events, times and places (shaping employment, education, healthcare, political participation and so on). Knowledge production presuming positivist epistemologies is typically deemed more acceptable and credible, so that this research has strategic advantages and arguably more visibility in and effect on mainstream IPE.

When gender is understood exclusively as an empirical category - a discrete variable - it can be 'added to' existing frameworks with productive results. But a critique of masculinism requires understanding gender as an analytical category - as a governing code that typically operates below our consciousness yet pervades our 'thinking' and perpetuates gender-differentiated valorizations. This orientation is associated with poststructuralism (or perhaps, constructivism) and is less familiar to and less accepted by the mainstream. I believe, however, it is indispensable for a critical feminist IPE, one that takes history, culture, embodiment, affect and intersectionality seriously and whose objective is a transformation of CRP on a global scale. In the absence of poststructuralist insights, we not only fail to recognize important complexities but also fail to understand how (typically unconscious) symbolic codes operate pervasively to shape material (read: economic) realities.

\section{CONCLUDING COMMENTS}

This chapter reveals how conceptualizations of PMM operate pervasively in orthodox IR, Economics and IPE, and variously in heterodox and feminist IPE. Like all analytical (and necessarily normative) premises, these conceptual orderings both enable and constrain our theory/practice. Drawing on critical orientations advanced by poststructural, postcolonial and feminist scholarship, I argue that the premises of PMM - both in isolation and interaction - are for the most part 'problematic': they tend to obstruct historical, holistic and critical understandings more adequate for 'seeing' and effectively transforming global inequalities - the CRP of today's globalization.

I offer three observations regarding the chapter's significance for feminist IPE. First, the chapter reveals multiple resistances and impediments to a critical feminist IPE, due primarily to masculinist premises. But insofar as positivist, modernist and masculinist premises interact, all exacerbate resistance to feminist and other critical interventions. Second and in spite of this, the chapter documents an impressive array of rigorous and insightful feminist contributions; these both expand conventional IPE and advance innovative and critical theory/practice. Third, while feminist achievements are impressive, the chapter urges feminists also to be cautious in adopting 'problematic premises.' 
No simple or singular perspective can be adequate for the complexities and challenges we confront. But heeding Mies's epigraph, we can aim for critical self-reflection regarding our conceptualizations and the questions of power they entail.

\section{NOTES}

1. Intersectionality signifies 'the complex, irreducible, varied, and variable effects which ensue when multiple axis of differentiation - economic, political, cultural, psychic, subjective and experiential intersect in historically specific contexts' (Brah and Phoenix 2004, p. 76; see also McCall 2005; European Journal of Women's Studies 2006). Importantly introduced by black feminist scholars, intersectionality has been taken up in varying ways and currently features in feminist debates. Please note that I use slashes to indicate similarity, hyphens to indicate contrast.

2. I do not claim that all feminists share this agenda but state it here to clarify my agenda and my preferred feminist orientation, as elaborated especially in Peterson (2003, 2012).

3. Debates and controversies attend how to label or specify the positions or commitments depicted here. I do not intend mine as a 'definitive' or uncontested account, only one that accords with well-developed and widely agreed points in the relevant critical literatures. For elaboration and references see Peterson (2012).

4. From a poststructuralist perspective, language, knowledge and power are co-constituting: the meaning of all concepts, objects and identities is produced through/by discursive practices that are embedded in relations of power, and because operations of power are not extricable from the power coded into our meaning systems, the latter constitute power relations manifested 'materially.'

5. I subsume post-positivism, interpretivism and postmodernism here to focus on what their critiques share that distinguishes them 'definitively' from positivist/empiricist and IR's narrowly 'rationalist' commitments.

6. More recent overviews of heterodox/critical IPE include Phillips (2005), Shields et al. (2011).

7. Exceptions include Chowdhry and Nair (2002), Beier (2005), Gruffydd Jones (2006), Hobson (2007), Agathangelou and Ling (2009).

8. Critiques of the positivist, economistic, Eurocentric and masculinist assumptions underpinning orthodox theory and methodologies include Cullenberg et al. (2001), Barker and Kuiper (2003), Barker and Feiner (2004), Zein-Elabdin and Charusheela (2004), Kaul (2008), Griffin (2009).

9. Critical/heterodox IPE scholarship more seriously engaging feminist insights includes Dickinson and Schaeffer (2001), Rupert and Solomon (2006), O'Brien and Williams (2013), Shields et al. (2011).

10. Overviews of feminist IPE include Peterson (2003, 2005), Waylen (2006), Bedford and Rai (2010), Marchand and Runyan (2011), Elias (2011), Rai and Waylen (2014); see also Figart and Warnecke (2013).

11. Critiques of heteronormativity and sexual politics as affecting IPE include Griffin (2007), Bedford (2009), Bergeron (2009), Lind (2010), Peterson (2014b).

12. Varying critiques include Bergeron (2004), Van Staveren (2008), Griffin (2009), Safri and Graham (2010), Elias (2013), Roberts (2014b), Prügl (2015) .

13. Gardiner (1997), Mies (1998), Dunaway (2001), Federici (2004), Hawkesworth (2008), Roberts (2012, 2014a).

14. Bergeron (2009), Politics \& Gender (2010), Safri and Graham (2010), LeBaron (2010), Kofman (2012), Peterson (2014b).

15. Agathangelou et al. (2008), LeBaron and Roberts (2010), LeBaron and Ayers (2013), Roberts (2014a), Pain (2015), Peterson (2017).

\section{REFERENCES}

Ackerly, Brooke A., Maria Stern and Jacqui True (eds) (2006), Feminist Methodologies for International Relations, Cambridge: Cambridge University Press. 


\section{Handbook on the international political economy of gender}

Agathangelou, Anna M. (2013), 'Neoliberal Geopolitical Order and Value', International Feminist Journal of Politics 15 (4), 453-76.

Agathangelou, Anna M. and L.H.M. Ling (2009), Transforming World Politics: From Empire to Multiple Worlds, London and New York: Routledge.

Agathangelou, Anna M., Daniel Bassichis and Tamara L. Spira (2008), 'Intimate Investments: Homonormativity, Global Lockdown, and the Seductions of Empire', Radical History Review 100, $120-43$.

Bakker, Isabella and Stephen Gill (eds) (2003), Power, Production and Social Reproduction, Houndmills, Basingstoke: Palgrave Macmillan.

Bakker, Isabella and Rachel Silvey (eds) (2008), Beyond States and Markets, London: Routledge.

Barker, Drucilla K. and Susan F. Feiner (2004), Liberating Economics, Ann Arbor, MI: University of Michigan Press.

Barker, Drucilla K. and Edith Kuiper (eds) (2003), Toward a Feminist Philosophy of Economics, London and New York: Routledge.

Bedford, Kate (2009), Developing Partnerships, Minneapolis, MN: University of Minnesota Press.

Bedford, Kate and Shirin Rai (2010), 'Feminists Theorize International Political Economy', Signs 36 (1), $1-18$.

Beier, J. Marshall (2005), International Relations in Uncommon Places, New York: Palgrave Macmillan.

Beneria, Lourdes (2008), 'The Crisis of Care, International Migration and Public Policy', Feminist Economics 14 (3), 1-21.

Bergeron, Suzanne (2004), Fragments of Development, Ann Arbor, MI: University of Michigan Press.

Bergeron, Suzanne (2009), 'An Interpretive Analytics to Move Caring Labor Off the Straight Path', Frontiers 30 (1), 55-64.

Brah, Avtar and Ann Phoenix (2004), 'Ain't I a Woman? Revisiting Intersectionality', Journal of International Women's Studies 5 (3), 75-86.

Chant, Sylvia and Carolyn Pedwell (2008), Women, Gender and the Informal Economy, Geneva: ILO.

Chowdhry, Geeta and Sheila Nair (eds) (2002), Power, Postcolonialism and International Relations, New York: Routledge.

Cullenberg, Stephen, Jack Amariglio and David F. Ruccio (eds) (2001), Postmodernism, Economics and Knowledge, London and New York: Routledge.

De Goede, Marieke (ed.) (2006), International Political Economy and Poststructural Politics, London: Palgrave Macmillan.

Dickinson, Torry D. and Robert K. Schaeffer (2001), Fast Forward: Work, Gender, and Protest in a Changing World, Lanham, MD: Rowman \& Littlefield.

Dunaway, Wilma A. (2001), 'The Double Register of History: Situating the Forgotten Woman and Her Household in Capitalist Commodity Chains', Journal of World-Systems Research VII (1), Spring, 2-29.

Eisenstein, Zillah R. (1998), Global Obscenities, New York: State University of New York Press.

Elias, Juanita (2010), 'Locating the "Everyday" in International Political Economy', International Studies Review 12 (4), 603-9.

Elias, Juanita (2011), 'Critical Feminist Scholarship and IPE', in Stuart Shields, Ian Bruff and Huw Macartney (eds), Critical International Political Economy: Dialogue, Debate and Dissensus, Houndmills, Basingstoke: Palgrave Macmillan, pp. 99-116.

Elias, Juanita (2013), 'Davos Woman to the Rescue of Global Capitalism', International Political Sociology 7 (2), 152-69.

Elson, Diane (ed.) (1991), Male Bias in the Development Process, Manchester: Manchester University Press.

Elson, Diane (2014), 'Economic Crises from the 1980s to the 2010s: A Gender Analysis', in Shirin M. Rai and Georgina Waylen (eds), New Frontiers in Feminist Political Economy, London and New York: Routledge, pp. 189-212.

Enloe, Cynthia (2014), Bananas, Beaches and Bases, 2nd edn, Berkeley, CA: University of California Press. European Journal of Women's Studies (2006), 'Special Issue: Intersectionality' 13 (3).

Federici, Silvia (2004), Caliban and the Witch: Women, the Body and Primitive Accumulation, New York: Autonomedia Pluto.

Figart, Deborah M. and Tonia L. Warnecke (eds) (2013), Handbook of Research on Gender and Economic Life, Cheltenham, UK and Northampton, MA, USA: Edward Elgar Publishing.

Friman, H. Richard (ed.) (2009), Crime and the Global Political Economy, Boulder, CO: Lynne Rienner.

Gardiner, Jean (1997), Gender, Care and Economics, London: Macmillan.

Gender \& Development (2010), 'Special Issue: Economic Crisis' 18 (2). July. 
Griffin, Penny (2007), 'Sexing the Economy in a Neo-liberal World Order', British Journal of Politics \& International Relations 9 (2), 220-38.

Griffin, Penny (2009), Gendering the World Bank, Houndmills, Basingstoke: Palgrave Macmillan.

Griffin, Penny (2011), 'Poststructuralism in/and IPE', in Stuart Shields, Ian Bruff and Huw Macartney (eds), Critical International Political Economy: Dialogue, Debate and Dissensus, Houndmills, Basingstoke: Palgrave Macmillan, pp. 43-58.

Griffin, Penny (2013), 'Gendering Global Finance', Men and Masculinities 16 (1), 9-34.

Grovogui, Siba N. (2001), 'Come to Africa: A Hermeneutics of Race in International Theory', Alternatives 26 (4), 425-48.

Gruffydd Jones, Branwen (ed.) (2006), Decolonizing International Relations, Lanham, MD: Rowman \& Littlefield.

Hawkesworth, Mary E. (2006), Globalization and Feminist Activism, Lanham, MD: Rowman \& Littlefield. Hawkesworth, Mary E. (2008), 'The Pragmatics of Iris Marion Young's Feminist Historical Materialism', Politics and Gender 4 (2), 318-26.

Hobson, John M. (2007), 'Is Critical Theory Always for the White West and for Western Imperialism? Beyond Westphilian Towards a Post-racist Critical IR', Review of International Studies 33 (S1), 91-116.

Hodgson, Geoffrey M. (1994), 'Some Remarks on "Economic Imperialism" and International Political Economy', Review of International Political Economy 1 (1), Spring, 21-8.

Hooper, Charlotte (2001), Manly States: Masculinities, International Relations, and Gender Politics, New York: Columbia University Press.

Hutchings, Kimberly (2008), 'Cognitive Short Cuts', in Jane L. Parpart and Marysia Zalewski (eds), Rethinking the Man Question, London: Zed Books, pp. 23-46.

ILO (2008), World of Work 2008, Geneva: International Labour Organization.

ISP Forum: Race and International Relations (2009), International Studies Perspectives 10 (1), February, 77-107.

Kaul, Nitasha (2008), Imagining Economics Otherwise: Encounters with Identity/Difference, London: Routledge.

Kofman, Eleonore (2004), 'Gendered Global Migrations', International Feminist Journal of Politics 6 (4), 643-65.

Kofman, Eleonore (2012), 'Rethinking Care Through Social Reproduction', Social Politics 19 (1), $142-62$.

LeBaron, Genevieve (2010), 'The Political Economy of the Household', Review of International Political Economy 17 (5), 889-912.

LeBaron, Genevieve and A.J. Ayers (2013), 'The Rise of a "New Slavery"? Understanding African Unfree Labour Through Neoliberalism', Third World Quarterly 34 (5), 873-92.

LeBaron, Genevieve and Adrienne Roberts (2010), 'Toward a Feminist Political Economy of Capitalism and Carcerality', Signs 36 (1), 19-44.

Lind, Amy (ed.) (2010), Development, Sexual Rights, and Global Governance, London: Routledge.

Ling, L.H.M. (2002), Postcolonial International Relations, London: Palgrave Macmillan.

Marchand, Marianne H. and Anne Sisson Runyan (eds) (2011), Gender and Global Restructuring, 2nd edn, London: Routledge.

McCall, Leslie (2005), 'The Complexity of Intersectionality', Signs 30 (3), 1771-800.

Mies, Maria (1998), Patriarchy and Accumulation on a World Scale, London: Zed Books.

Murphy, Craig N. and Roger Tooze (eds) (1991a), The New International Political Economy, Boulder, CO: Lynne Rienner.

Murphy, Craig N. and Roger Tooze (1991b), 'Getting Beyond the "Common Sense" of the IPE Orthodoxy', in Craig N. Murphy and Roger Tooze (eds), The New International Political Economy, Boulder, CO: Lynne Rienner, pp. 11-31.

Nitzan, Jonathan and Shimshon Bichler (2009), Capital as Power: A Study of Order and Creorder, London: Routledge.

O’Brien, Robert and Marc Williams (2013), Global Political Economy, 4th edn, London: Palgrave Macmillan.

Pain, Rachel (2015), 'Intimate War', Political Geography 44, 64-73.

Parpart, Jane L. and Marysia Zalewski (eds) (2008), Rethinking the Man Question, London: Zed Books.

Parreñas, Rhacel Salazar (2001), Servants of Globalization: Women, Migration and Domestic Work, Stanford, CA: Stanford University Press.

Peterson, V. Spike (2003), A Critical Rewriting of Global Political Economy: Integrating Reproductive, Productive, and Virtual Economies, London and New York: Routledge. 


\section{Handbook on the international political economy of gender}

Peterson, V. Spike (2005), 'How (the Meaning of) Gender Matters in Political Economy', New Political Economy 10 (4), 499-521.

Peterson, V. Spike (2007), 'Thinking Through Intersectionality and War', Race, Gender \& Class 14 (3-4), 10-27.

Peterson, V. Spike (2010a), 'Informalization, Inequalities and Global Insecurities', International Studies Review 12 (2), 244-70.

Peterson, V. Spike (2010b), 'A Long View of Globalization and Crisis', Globalizations 7 (1), 187-202.

Peterson, V. Spike (2012), 'Rethinking Theory: Inequalities, Informalization and Feminist Quandaries', International Feminist Journal of Politics 14 (1), 1-31.

Peterson, V. Spike (2014a), 'Sex Matters: A Queer History of Hierarchies', International Feminist Journal of Politics 16 (3), September, 389-409.

Peterson, V. Spike (2014b), 'Family Matters: How Queering the Intimate Queers the International', International Studies Review 16 (4), 604-8.

Peterson, V. Spike (2017), 'Towards Queering the Globally Intimate', Political Geography 56, January, 114-16.

Phillips, Nicola (ed.) (2005), Globalizing Political Economy, New York: Palgrave Macmillan.

Politics \& Gender (2010), 'Critical Perspectives Section: Global Householding' 6 (2), 271-304.

Prügl, Elisabeth (2015), 'Neoliberalising Feminism', New Political Economy 20 (4), 614-31.

Rai, Shirin M. (2002), Gender and the Political Economy of Development, Cambridge: Polity.

Rai, Shirin (2008), The Gender Politics of Development: Essays in Hope and Despair, New York: Zed Books.

Rai, Shirin M. and Georgina Waylen (eds) (2014), New Frontiers in Feminist Political Economy, London and New York: Routledge.

Rai, Shirin, Catherine Hoskyns and Dania Thomas (2014), 'Depletion', International Feminist Journal of Politics 16 (1), January, 86-105.

Roberts, Adrienne (2012), 'Financial Crisis, Financial Firms ... and Financial Feminism? The Rise of "Transnational Business Feminism" and the Necessity of Marxist-Feminist IPE', Socialist Studies 8 (2), $85-108$.

Roberts, Adrienne (2014a), "Borrowed Time”: A Historical Materialist Account of Capitalist States, the Law and the Incarceration of "Undeserving" Debtors', Critical Sociology 4 (5), 669-87.

Roberts, Adrienne (2014b), "The Political Economy of "Transnational Business Feminism": Problematising the Corporate-led Gender Equality Agenda', International Feminist Journal of Politics 17 (2), 209-31.

Runyan, Anne Sisson and V. Spike Peterson (2014), Global Gender Issues in the New Millennium, 4th edn, Boulder, CO: Westview Press.

Rupert, Mark and M. Scott Solomon (2006), Globalization and International Political Economy, Lanham, MD: Rowman \& Littlefield.

Safri, Maliha and Julie Graham (2010), 'The Global Household', Signs 36 (1), 99-125.

Shields, Stuart, Ian Bruff and Huw Macartney (eds) (2011), Critical International Political Economy, Houndmills, Basingstoke: Palgrave Macmillan.

Tickner, J. Ann (2005), 'Gendering a Discipline: Some Feminist Methodological Contributions to International Relations', Signs 30 (4), 2173-88.

Van Staveren, Irene (2008), 'The Gender Bias of the Poverty Reduction Strategy Framework', Review of International Political Economy 15 (2), 289-313.

Waylen, Georgina (2006), 'You Still Don't Understand: Why Troubled Engagements Continue Between Feminists and (Critical) IPE', Review of International Studies 32 (1), 145-64.

Zein-Elabdin, Eiman O. and S. Charusheela (eds) (2004), Postcolonialism Meets Economics, London and New York: Routledge. 